\title{
An Investigation of the Relationship Among Machiavellianism, Ethical Beliefs and Tax Compliance Behaviour: A Preliminary Study on Selected Individual Taxpayers in Malaysia
}

Afidah Sapari, Siti Anis Nadia, Vani Tanggamani

To Link this Article: http://dx.doi.org/10.6007/IJARBSS/v10-i12/8374

DOI:10.6007/IJARBSS/v10-i12/8374

Received: 20 October 2020, Revised: 02 November 2020, Accepted: 24 November 2020

Published Online: 10 December 2020

In-Text Citation: (Sapari et al., 2020)

To Cite this Article: Sapari, A., Nadia, S. A., \& Tanggamani, V. (2020). An Investigation of the Relationship Among Machiavellianism, Ethical Beliefs and Tax Compliance Behaviour: A Preliminary Study on Selected Individual Taxpayers in Malaysia. International Journal of Academic Research in Business and Social Sciences, 10(12), 838-858.

Copyright: (C) 2020 The Author(s)

Published by Human Resource Management Academic Research Society (www.hrmars.com) This article is published under the Creative Commons Attribution (CC BY 4.0) license. Anyone may reproduce, distribute, translate and create derivative works of this article (for both commercial and non-commercial purposes), subject to full attribution to the original publication and authors. The full terms of this license may be seen at: http://creativecommons.org/licences/by/4.0/legalcode

Vol. 10, No. 12, 2020, Pg. 838 - 858

Full Terms \& Conditions of access and use can be found at http://hrmars.com/index.php/pages/detail/publication-ethics 


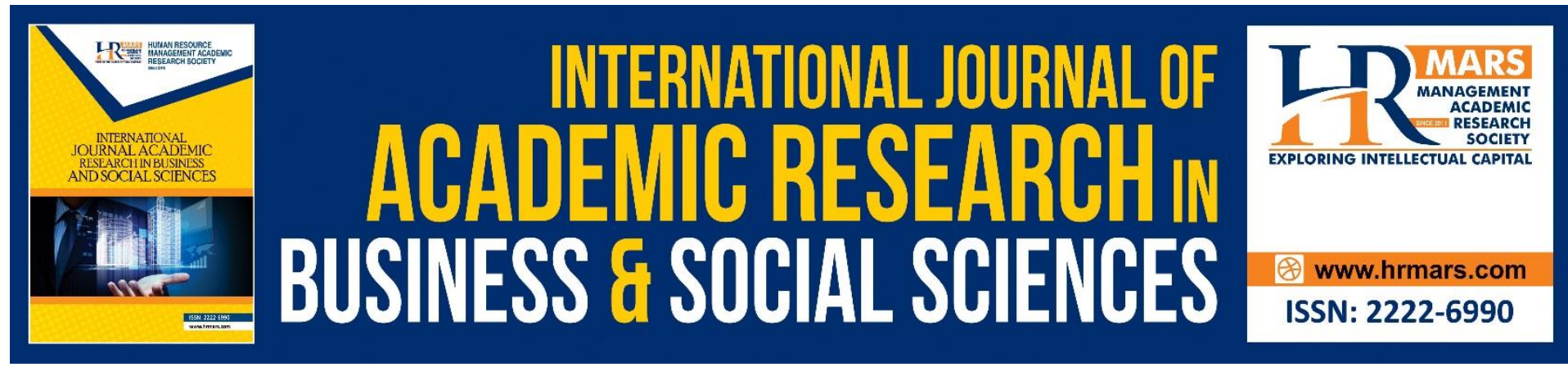

\title{
An Investigation of the Relationship Among Machiavellianism, Ethical Beliefs and Tax Compliance Behaviour: A Preliminary Study on Selected Individual Taxpayers in Malaysia
}

\author{
Afidah Sapari, Siti Anis Nadia, Dr Vani Tanggamani \\ Faculty of Accountancy, Universiti Teknologi MARA, 78000 Melaka, Malaysia
}

\begin{abstract}
Taxpayer compliance has always been of great importance to the revenue authorities. To comprehend and understand the complex issue surrounding compliance behaviour and its inherent moral dilemmas, taxpayer ethics needs to be understood. Prior literature showed that tax researchers are increasingly seeking to include ethics as one of the variables in the study of tax compliance behaviour. However there are different schools of thought as to whether general ethical beliefs or the specific tax ethical belief is more appropriate to the tax moral dilemma. The present study fills the gap from the literature through investigating both the effect of general ethical value (Machiavellianism) and tax ethical value towards tax compliance behaviour. A set of questionnaire was distributed to taxpayers in some public and private organizations. These preliminary findings reveal that Machiavellian respondents judged underreporting income as less unethical than Nonmachivellian respondents. Respondents who chose not to report (not comply) their income were less ethical. Results showed that there is a significant relationship between Machiavellianism and compliance behaviour. However it appears that there is no significant relationship between tax ethical beliefs and compliance behaviour.
\end{abstract}

Keyword: Machiavellianism, Tax Ethics, Tax Compliance Behaviour

\section{Introduction}

Self-assessment (SA) system for the Malaysian individual taxpayers was introduced in the year 2004 and implemented with careful consideration to ensure its operational success. Although it intends to promote voluntary compliance, this system has experience adverse perceptions of Inland Revenue Board (IRB)'s responsibility. This system was perceived as a way of transferring the burden of estimating tax payable onto the shoulders of the taxpayers (Choong, 2008). Six years after the SA system was implemented, the issue of compliance is still being discussed as whether, SA system can improve the compliance of taxpayers or vice versa.

It is understood that the overriding objective of tax is to raise revenue for the country. The degree to which this objective is achieved depends partly on the motivational strength the 
tax system instils in taxpayers to submit the tax returns on time, reporting the correct amount subject to tax and paying the correct amount of tax. On the surface, the SA system may appear to be able to enhance compliance; however, tax compliance goes further than the need to comply with the law. It involves the need to change the mind sets, attitudes and obligations of individual taxpayers. How do Malaysian taxpayers react with this statutory obligation? The question of whether each taxpayer was aware of the consequences of the new system and voluntary comply by completing the tax return, reporting the correct amount of income subject to tax and paying the correct amount of tax to the IRB can be answered by analysing their behaviour in filing, reporting and paying income tax liability.

As a developing country, "... it is important to understand the behaviour of different groups of taxpayers (based on income level, occupational groupings, locality, etc) so that remedial steps and new strategies can be developed to overcome negative perceptions...", (Singh, 2005, p. 73) on tax non-compliance. The identification of taxpayer's moral value (general ethical value and tax specific ethical value) and their relationship with tax compliance behaviours might help the policy makers to improve strategies in tax compliance. As Ghosh and Crain (1995, p. 353) stated "...to understand tax evasive behaviour better requires noneconomic factors in the analysis such as ethical standards and risk attitudes."

The relationship between ethical beliefs and tax compliance is well documented, but only one major study examined the role of ethics in tax compliance decision by exploring the relationships among both general ethical beliefs, tax specific ethical beliefs and tax compliance behaviour (Henderson and Kaplan, 2005). The correlation between both general ethics and tax ethics in tax compliance behaviour will be an interesting finding since prior studies mainly focused on one aspect of moral value i.e. either general ethics (Ghosh and Crain, 1995; Trivedi, Shehata and Mestelman, 2005; Henderson and Kaplan, 2005) or tax ethics (Song and Yarbrough, 1978; Kaplan and Reckers, 1985; Reckers, Sanders and Roark, 1994; Hanno and Violette, 1996; Bobek and Hatfield, 2003).

The purpose of this paper is to present the findings of a preliminary study on the relationship between individual differences, moral value (both general ethical value and tax specific ethical value) and tax compliance behaviour. Since tax compliance was proved to be affected by the changes in tax structure (such as tax law, tax rate and tax audit) it is important for the IRB to identify and understand other non-economic factors in enhancing tax compliance. Designing effective policies in enhancing tax compliance not only focusing on economic and deterrence factors, it requires understanding of the behavioural aspects of the tax compliance decision of the taxpayers.

Statistics shows that under the SA System, in the year 2004 to 2007 the percentage of failure to file the tax returns between 20 and 41 percent. The high rate of non- filing of tax returns constitutes powerful evidence of persistent income tax non-compliance in filing tax return in Malaysia. In 2005, a total of 67,771 compound amounting to RM13.68 million were charged to the taxpayers due to failure to submit their tax return within the stipulated time frame. Even though the IRB has come out with many activities in enhancing compliance such as advertisements, aggressive campaigns, and increasing the quality of their services, the issue of tax compliance is still debatable. What are the factors that affect Malaysian individual taxpayers in fulfilling their tax compliance decision? 
Filing compliance includes filing the tax return within the stipulated time frame. However, in the year 2006 and 2007, 41 percent and 27 percent Malaysian individual taxpayers respectively failed to submit the tax return (BE Form) within the stipulated time frame. It shows that the compliance rate to submit the tax returns within the time frame is low. Failure to return the tax return within the stipulated time frame is an issue of filing compliance. Under SA system, it is the responsibility of the taxpayers to return the tax return within the time frame. Failure to comply with this obligation give raise to a penalty to be imposed and this has becomes the problems to the IRB to ensure the effectiveness of the tax system.

Failure to file a complete tax return is another issue of tax non-compliance. In the year 2005 to 2007 , statistics by IRB shows more than 9,000 Malaysian individual taxpayers failed to file completed tax returns. Submitting incomplete tax return may affects the effectiveness of the whole tax system and also indicates a substantial loss in tax revenue. In addition, for the years 2004 to 2007, millions of cases on mistakes (intentional or unintentional) were found in the tax returns, particularly in the BE Form submitted by the taxpayers. These mistakes include claiming excessive relief, incorrect tax rate and rebate, calculate wrong chargeable income and calculate wrong tax payable. Under the SA System, taxpayers are expected to provide accurate information to the best of their knowledge as original supporting documentation are no longer required to be submitted to the IRB.

The lack of knowledge among taxpayers and the absence of massive assessment as practised under official assessment system have provided greater chance for the taxpayers to take the risk of evading since no supporting documents need to be submitted to the IRB when filing tax returns. Taxpayers are only required to keep the original documents for six years for tax audit purposes.

This paper is presented in five parts. Part I provides an overview and objectives of the study. Part II provides an overview of the relevant literature on tax compliance, Machiavellianism and tax ethics, and this is followed by a hypothesized model and hypotheses development. The research methodology is then explained briefly in part III. Part IV of the study provides a discussion on the findings. Finally, the conclusion, the limitations of the study and the future research are discussed in part $\mathrm{V}$.

\section{Literature Review and Hypotheses Development}

Prior literature on tax compliance research has been dominated from the economic theories that believe taxpayers seek to maximize their individual benefits and thus try to evade tax where the threat of sanctions does not outweigh the benefits of evasion. This is in line with the economic-of-crime approach by Allingham and Sandmo (1972) who presented a formal economic view model. This model showed that the extent of tax evasion was negatively correlated with the probability of detection and the degree of punishment. In such, the higher the probability of taxpayers being detected and punished, the lower the probability of tax evasion. The taxpayers thus rationally and without concern for right and wrong, choose the option that promises the greatest profits (self-maximization).

Many economists have taken the expected utility theory influenced by the model of Allingham and Sandmo's findings to suggest that deterrence policy should be used to enforce taxpayers to obey the law (Cuccia, 1994; Plumley, 1996). They believed that harsh sanctions 
and penalties should be used to deter people from breaking the law. However, Alm (1991) argued that even though audit and penalty rates affect tax compliance, they do not totally explain why taxpayers obeyed the tax rules. Furthermore, given a rather mild penalties, deterrence still cannot account for the generally high level of compliance (Alm, McClelland \& Schulze, 1992).

This motivated researchers to expand the traditional expected utility theory and deterrence theory as well as to identify and check the relevance of other theories or to implement new experiments focusing on new variables that could possible affect tax compliance behaviour. These researchers challenged the economic deterrence models by Allingham and Sandmo (1972) and stressed that non-economic social factors such as social norms, attitudes and individual morality and moral obligation (personal ethic) could have a significant impact on tax compliance behaviour (e.g., Vogel, 1974; Reckers, Sanders \& Roark, 1994; Ghosh \& Crain, 1995; Hanno \& Violette, 1996; Torgler, 2002; Bobek \& Hatfield, 2003; Trivedi, Shehata \& Lynn, 2003; Wenzel, 2004a, 2005a, 2005b; Trivedi, Shehata \& Mestelman, 2005; and Bobek, Roberts \& Sweeney, 2007). Rather than just being extrinsically motivated by material incentives, intrinsic motivations largely determine tax compliance (Carroll, 1987). Indeed, the explanation for taxpayers' behaviour goes beyond economics theories to psychology, sociology and criminology (Trivedi et al, 2003).

\section{Tax Compliance}

Tax compliance can be defined as "...taxpayer files all required tax returns at the proper time and return accurately report tax liability in accordance with the Internal Revenue Code, regulations, and court decisions applicable at the time the return is filed." (Roth, Scholz \& Witte, 1989, p.21). This implies that taxpayer needs to exercise care in the preparation of the tax returns by avoiding unintentional non-compliance and preventing deliberates evasion of tax. Voluntary compliance can be treated as having three components: (i) filing compliance means timely filing of tax returns; (ii) reporting compliance means reporting accurate income subject to tax including accurate claims of deductions, exemptions, and tax credits; and (iii) payment compliance means timely and correctly paying of all tax obligations (Plumley, 1996; James \& Alley, 2002). James and Alley (2002) also define tax compliance in a wider perspective under sociological and psychological approach of which tax compliance is "...the willingness of taxpayers to act in accordance with their spirit as well as the letter of tax law voluntarily" (p.33).

Unlike compliance with many criminal laws, which require individuals to refrain from certain prescribed activities, compliance with reporting requirements requires a series of actions that may involve substantial effort, reading and computation skill, and judgements (Cowell, 1992). For this reason non-compliance may occur in a variety of ways and for a variety of reasons other than a deliberate decision to understate tax liability. Tax non-compliance is the failure, intentional or unintentional of taxpayers to meet their tax obligations (Kinsey, 1985). Failure to file a tax return, late payment of taxes, understatement of gross income and overstatement of deductions, exemptions, credits or rebates are considered as tax noncompliance (Plumley, 1996). Reporting tax non-compliance can be referred as underreporting or over reporting of tax liability (Hanefah, 2007). Underreporting is when a tax liability is less than the accurate amount. On the other hand, when the taxpayer reports a liability greater than the amount subject to tax, it is considered as over reporting. 


\section{Moral Value}

Kohlberg's (1969) Cognitive Moral Development theory developed a framework of moral value on the basis of justice and fairness which assists an individual to deal with ethical decision-making processes. In a decision making process, moral value can be defined as normative systems of rules of conduct developed to provide guidance in social or interpersonal settings (Hogan, 1973 cited in Reckers et al., 1994). A study on the role of moral value or ethics in tax compliance behaviour has become the interest of tax researchers. In making a decision whether to comply or not to comply with the tax laws, it involves an ethical component since individual will use their moral values held in making judgments on their decision. Taxpayers must draw on their perceived values and codes of conduct to assess the "rightness" or "wrongness" in making tax compliance decision (Chan, Troutman \& O'Bryan, 2000).A person's ethical value is related to personality factors, such as moral reasoning, authoritarianism and Machiavellianism, egoism, norm dependency and values (Kirchler, 2007, p.59).

Pioneers in the studies on moral value or moral reasoning in tax compliance decisions include Kaplan and Reckers (1985), Ghosh and Crain (1995) and Kaplan et al., (1997). In tax compliance decision, moral value play an important role since taxpayers need to draw their ethical value regarding filing, reporting and paying in order to ensure the rightness or wrongness of the decision. Tax compliance research supports a consistently positive relationship between moral commitment and measures of tax compliance behaviour (Roth et al., 1989) on which moral beliefs were a significant determinant of compliance. When faced with tax compliance dilemmas, it is generally believed that moral value can serve as guidelines for taxpayers on how to act rightly and justly (Ho \& Wong, 2008).

Studies using moral values are sparse and become very important. Tax researchers are more concerned to include moral value as one of the variables in tax compliance behaviour study (e,g, Song \& Yarbrough, 1978; Roth et al., 1989; Kaplan, Reckers \& Roark, 1988; Reckers et al., 1994; Ghosh \& Crain, 1995; Kaplan, Newberry \& Reckers, 1997; Erard \& Feinstein, 1994; Chan et al., 2000; Bobek \& Hatfield, 2003; Singh, 2003; Trivedi et al., 2003; Wenzel, 2004a, 2004b, 2005a, 2005b; Henderson \& Kaplan, 2005; Trivedi et al., 2005; Ho \& Wong, 2006, 2008; Blanthorne \& Kaplan, 2008). These studies find that moral value has consistently show a negative association with tax evasion behaviour. In other words, the higher the moral value, the lower the taxpayer intention of not complying with tax.

In determining whether a study should use general ethical belief or specific tax ethical belief, researchers have come out with a different school of thought. The consistency theory suggests that an individual will behave in a manner consistent with his general ethical beliefs (e.g., an individual who is not cheating during exam will not litter) (Henderson\& Kaplan, 2005). This belief supported the study of Trivedi et al. (2003) who found that the degree to which taxpayers comply is positively affected by their level of moral development (general ethics), value orientation and risk aversion. Another study by Trivedi et al., (2005) also confirmed that general ethical belief will influence intention and intention will influence taxpayer behaviour. Tax evasion intentions are significantly lower for those taxpayers with high moral reasoning in making decision (Kaplan et al., 1997). It is argued that individuals with high moral reasoning might be less compliant when they judge certain tax to be unfair. 


\section{Machiavellianism}

The concept of Machiavellianism was introduced by Christie and Geis in their 1970's publication. As originally conceived Machiavellianism was constructed with the intention to capture a manipulative, cold and calculating personality. Someone who is prone to the use of manipulative or deceitful tactics and who lacks a concern for conventional morality will engage in unethical behaviour across a variety of settings. Individuals who score high on Machiavellianism tend to be less distracted by moral concerns such as fairness and justice, and better able to single-mindedly pursue winning (Geis, Weinheimer \& Berger, 1970).

Generally Machiavellianism defines an orientation towards one's own interests that stretches beyond the limit of ethical standards. Individuals who are considered to have Machiavellian characteristics have relatively low affective connections to others. They are characterised by emotional distance, are loosely bound to conventional moral standards and ideologies, and have strong utilitarian preferences (Kirchler, 2007, p. 60-61). Machiavellian behaviour is expected to be an additional construct that impacts ethical reasoning processes or helps explain differences in ethical reasoning (Christie \& Geiss, 1970). Individuals with higher scores on the Machiavellian scale tend to be more deceitful (McLaughlin, 1970), less moral, more indifferent to societal needs (Long, 1976) and more manipulative. A study by Bodey and Grace (2004) found significant relationship between self-monitoring, perceived control and selfefficacy with attitude to complaining while self-efficacy and Machiavellianism was significantly related to propensity to complain.

Prior study by Ghosh and Crain (1995) found that taxpayers with stronger Machiavellian orientations were more likely to engage in intentional non-compliance. Other study on egoism measured by Machiavellianism showed evidence on which tax evaders had higher loadings than non-evaders(Webley, Cole \& Eidjar's 2001). Trivedi and others have found that the value orientation in terms of egoism and altruism, that is on the extreme of wanting the best for others determined compliance (Trivedi et al., 2003). Machiavellianism construct appears to be relevant to many ethical decision-making contexts. Shafer and Simmons (2008) in their study on the effects of attitudes toward corporate ethics and social responsibility on Hong Kong tax professionals confirmed that Machiavellianism affects tax advisors' expressed viewpoints toward the importance of corporate ethics and social responsibility, which affect professional judgements toward aggressive tax minimisation. High Machiavellians are more likely to endorse traditional stockholder view of corporate responsibility and less likely to support the stakeholder view which recognises corporate responsibilities to a broader range of potential stakeholders (Shafer \& Simmons, 2008). Machiavellianism also had significant direct effects on ethical and social responsibility judgements. Thus, based on the prior literature, it is therefore hypothesised that:

$H_{1}$ : Machiavellian taxpayers will judge underreporting income as less unethical compared to Nonmachiavellian taxpayers

$H_{2:}$ There is a relationship between taxpayer's Machiavellian orientations with tax compliance behaviour 


\section{Tax Ethics}

When faced with tax compliance dilemmas, moral value can serve as guidelines for taxpayers on how to act rightly and justly (Ho \& Wong, 2008). The importance of moral value has also been highlighted by Jackson and Milliron (1986) who suggested that “...specific ethical measures are probably the most fruitful area in tax compliance" (p.137). Ethics in general (ethical orientation) reflect an individual's collective beliefs about right and wrong whereas ethics in tax context (ethical evaluation) represents specific ethical beliefs about the context of tax compliance (Henderson \& Kaplan, 2005). Song and Yarbrough (1978) defined ethics in tax context as the norms of behaviour governing citizens as taxpayers in their relationship with the government and was found to have significant effect on compliance behaviour.

Reckers et al., (1994) believe that "...ethical behaviour tends to be situation specific and measures of ethical beliefs must also be a situation specific" (p. 826). It shows that measurement of ethical belief that relies on specific situation (ethical evaluation) believes that individual's attitude and ethical belief differ depending on specific situation. These beliefs supported the study by Song and Yarbrough (1978) who found that taxpayers ranked tax evasion slightly more serious than stealing a bicycle. In general, an individual will behave in a manner differently with his general ethical beliefs depending on the context-specific scenarios (e.g., an individual who litters may be not cheating during exam or individual who litters may be complying with tax laws). Other tax compliance study by Blanthorne and Kaplan (2008) used the direct measurement of underreporting ethics related to tax rather than a general measure of ethical orientation based on the tendency that ethical behaviour is to be situation specific. Thus, based on the prior literature, it is therefore hypothesised that:

$H_{3}$ : There is a relationship between taxpayer's tax ethical beliefs and tax compliance behaviour

From the above discussion, the hypothesized model in Figure 1 displays the role of Machiavellianism, tax ethical beliefs and tax compliance behaviour. This model shows there is a relationship between Machiavellianism orientations towards respondents' tax ethical beliefs and tax compliance behaviour. In line with that, tax ethical beliefs will affect tax compliance behaviour.

Figure 1: Hypothesized model of the role of Machiavellianism and tax ethical beliefs in tax compliance behaviour

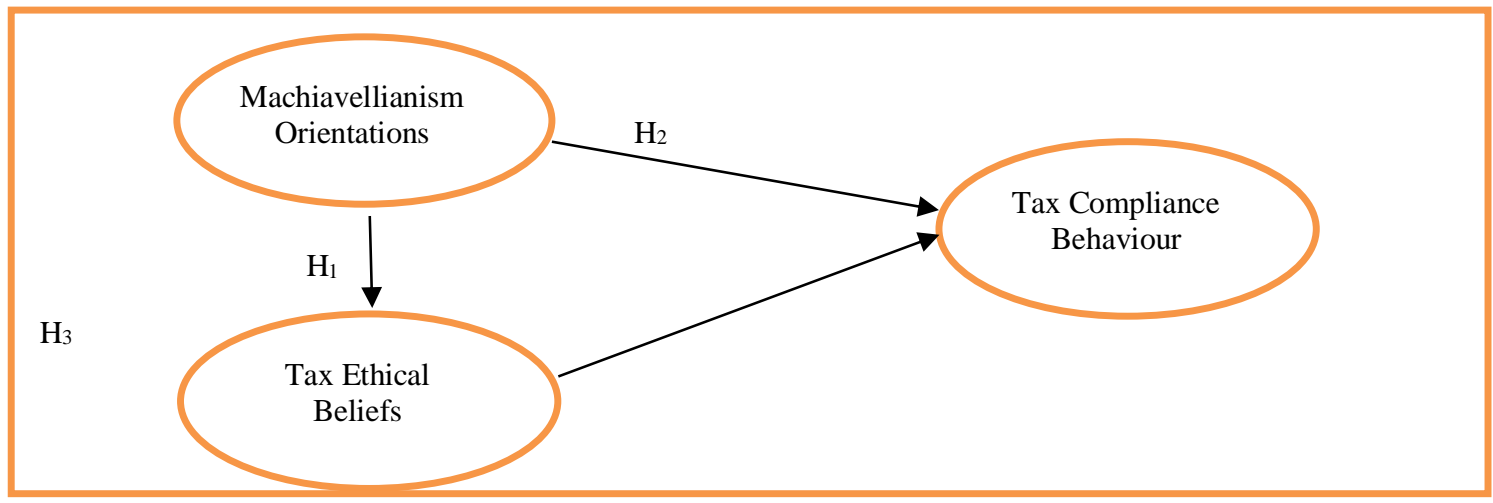




\section{Research Methodology}

The survey method is the main research design for this study to test the hypotheses as it believes that surveys are appropriate for research questions about self-reported beliefs and behaviours (Neuman, 2003). Data are collected through survey questionnaires distributed to the 60 individuals (using convenience sampling) comprise of academicians, employees of government agencies, employees of the private sector and other individuals who have experience in paying tax. A covering letter was included to describe the nature of the study and to ensure that the study was not conducted by or on behalf of the IRB.

The survey instrument consists of three parts. Part I consists of demographic and socioeconomic background such as age, gender, level of education, designation, level of income, working sector, tax filing experience and tax preparer. Part II consists the measurement of taxpayer's Machiavellian orientations. It is measured based on Christie and Geis (1970, p. 1718)'s Machiavellianism scale using scores from the Mach IV scale. A 20-item instrument designed to measure the respondents' feelings on whether a person believes that others are susceptible to manipulation in interpersonal situations. It consists of ten highest-related items in favour of Machiavellian statements, and the ten highest-related items not favourable of Machiavellian statements (reverse scored). These 20-items are based on a 7-point Likert scale ranging from " 1 " (strongly disagree) to " 7 " (strongly agree). These scales have been used extensively in previous research in business ethics and have been found to possess reasonable reliability and validity (Rayburn and Rayburn, 1996; Shafer and Simmons, 2008). A single score for Machiavellianism is computed by summing responses to the individual items from the Machiavellian questions. The total score at the theoretically neutral point is $80(4 * 20$ items). The minimum score is 20 ( $1 * 20$ items) and the maximum score is 140 ( $7^{*} 20$ items). Respondents having a Machiavellian score of 80 or more are coded as Machiavellian, whereas respondents having a Machiavellian score of less than 80 are coded as Nonmachiavellian (Rayburn \& Rayburn, 1996, p. 1213).

Part III consists of statements measuring taxpayers' specific tax ethical beliefs. It was constructed with the intention to capture taxpayer's ethical beliefs towards tax activities of underreporting income (Blanthorne \& Kaplan, 2008; Darwish et al., 2020). The five statements of underreporting ethics relate to (1) not feeling guilty if underreport; (2) underreporting goes against principle; (3) morally wrong to underreport; (4) not ethically wrong to underreport and (5) dishonest to underreport. Two of the items on not feeling guilty if underreport and a judgment that it is not ethically wrong to underreport, were reverse coded. For each of the five statements, a 7-point Likert scaleranging from "1" (strongly disagree) to "7" (strongly agree) was used.The higher number indicates that underreporting is judged to be more unethical and lower number indicates that underreporting is judged to be less unethical (Blanthorne \& Kaplan, 2008).

For compliance behaviour (Part IV), two hypothetical tax scenarios relating to intentional noncompliance were developed. Respondents were asked to respond on tax scenario 1, i.e. on casual income received as a home handy man and scenario 2, i.e. hobby income received as a computer expert. Both taxpayers in the scenarios did not comply to report their income to the IRB. Respondents' responses on the likelihood of not reporting their income as what have been done by the taxpayers in the earlier scenarios were measured on a 7-point Likert scale 
ranging from "1" (very unlikely) to "7" (very likely). The higher numbers indicate "noncompliance" while the lower numbers indicate "compliance".

\section{Findings}

The data obtained from the survey was coded and analysed using SPSS package. Cronbach Alpha was used to test the reliability of the two factors that are Machiavellianism and tax ethics. Table 1 shows the result of Cronbach Alpha, Kaiser-Meyer-Oklin (KMO) and Bartlett's Test of Sphericity. Cronbach Alpha for Machiavellianism $(\alpha=0.634)$ represented satisfactory internal consistency of the measures whereas for tax ethics $(\alpha=0.764)$ represented sufficient indicators of the internal consistency of the measures. The data component showed a KaiserMeyer Oklin (KMO) value of greater than 0.5 and Bartlett's Test of Sphericity $(p<0.000)$ indicated that the construct validity of each item was significantly supporting the factorability of the correlation matrix. Therefore, it can be concluded that the questions used in the survey were reasonably valid and reliable.

Table 1

Reliability analysis

\begin{tabular}{|l|c|c|c|c|}
\hline \multicolumn{1}{|c|}{ Factors } & No of items & KMO & $\begin{array}{c}\text { Cronbach } \\
\text { Alpha }\end{array}$ & $\begin{array}{c}\text { Bartlett's Test } \\
\text { of Sphericity }\end{array}$ \\
\hline Machiavellianism & 20 & .543 & 0.634 & .000 \\
\hline Tax ethics & 5 & .767 & 0.764 & .000 \\
\hline
\end{tabular}

The relevant demographic information of the sample is set out in Table 2 . The majority $(67.5$ $\%)$ of respondents were in the 36-55 age brackets. The respondents comprised of 27 females and 16 males. 75 percent of the respondents are married and 74 percent of them are at least, holders of diploma, degree or above. With regards to filing experience, the majority of the respondents ( $77 \%$ ) have experienced of filing tax returns for more than seven years. Only 33 percent of the respondents have filed their tax returns with the help from others and tax preparer while 67 percent of the respondents have filed their tax returns on their own. 
Table 2

Summary of demographic data

\begin{tabular}{|c|c|c|c|c|c|}
\hline Variable & Frequency & Percent & Variable & Frequency & Percent \\
\hline Age & & & Monthly income & & \\
\hline Below 30 yrs & 6 & 14.0 & Below 2000 & 2 & 4.7 \\
\hline 31 to 35 yrs & 8 & 18.6 & 2001 to 4000 & 21 & 48.8 \\
\hline 36 to 40 yrs & 11 & 25.6 & 4001 to 6000 & 12 & 27.9 \\
\hline 41 to $45 \mathrm{yrs}$ & 7 & 16.3 & 6001 to 8000 & 6 & 14.0 \\
\hline 46 to $50 \mathrm{yrs}$ & 4 & 9.3 & 8001 to 10000 & 2 & 4.7 \\
\hline \multirow[t]{2}{*}{51 to 55 yrs } & 7 & 16.3 & & & \\
\hline & & & Working sector & & \\
\hline Gender & & & Government & 14 & 32.6 \\
\hline Male & 16 & 37.2 & Private & 27 & 62.8 \\
\hline Female & 27 & 62.8 & Self-employed & 2 & 4.7 \\
\hline Marital & & & Filing experience & & \\
\hline Married & 32 & 74.4 & Less than 1 year & 4 & 9.3 \\
\hline Single & 8 & 18.6 & 1-3 year & 5 & 11.6 \\
\hline \multirow[t]{2}{*}{ Divorce } & 3 & 7.0 & 4-6 year & 1 & 2.3 \\
\hline & & & 7-10 year & 4 & 9.3 \\
\hline Qualifications & & & More than 10 & 29 & 67.4 \\
\hline SPM/MCE & 10 & 23.3 & year & & \\
\hline STPM & 1 & 2.3 & & & \\
\hline Diploma & 9 & 20.9 & Tax filing preparer & 29 & 67.4 \\
\hline Bachelor & 13 & 30.2 & Myself & 4 & 9.3 \\
\hline degree & 9 & 20.9 & My spouse & 5 & 11.6 \\
\hline Master Degree & 1 & 2.3 & Friends & 1 & 2.3 \\
\hline \multirow[t]{2}{*}{ PhD } & & & Relatives & 4 & 9.3 \\
\hline & & & Tax preparer (agen & & \\
\hline
\end{tabular}

The respondents' Machiavellianism scores are presented in Table 3. It appeared that 74 percent of the respondents were categorised as "Nonmachiavellian" while only 26 percent of the respondents were categorised as "Machiavellian".

Table 3

Score of Machiavellianism orientations

\begin{tabular}{clcc}
\hline Total Scores & Category & Frequency & Percentage \\
\hline $20-79$ & Nonmachiavellian & 32 & 74.4 \\
$80-140$ & Machiavellian & 11 & 25.6 \\
\hline
\end{tabular}

Table 4 exhibits the mean results of the individual measures of underreporting ethics. The higher mean value for all underreporting ethics measurements indicated that the respondents are ethical in tax reporting and believed underreporting income to be more unethical. 
Table 4

Descriptive statistics for underreporting ethics

\begin{tabular}{llcccc}
\hline Indicators & Code & Min & Max & Mean & Std. Dev. \\
\hline Not feeling guilty if underreport & TE1R & 1 & 7 & 4.47 & 1.817 \\
Underreporting goes against principle & TE2 & 1 & 7 & 4.79 & 1.611 \\
Morally wrong to underreport & TE3 & 1 & 7 & 5.09 & 1.411 \\
Not ethically wrong to underreport & TE4R & 1 & 7 & 4.42 & 1.762 \\
Dishonest to underreport & TE5 & 1 & 7 & 4.88 & 1.788 \\
\hline
\end{tabular}

( $R=$ reverse coded item)

Table 5 provides additional details regarding individual mean for all underreporting ethics measurements for both Machiavellian and Nonmachiavellian respondents. The results showed that the mean responses among Machiavellian respondents (in comparison to Nonmachiavellian respondents) were slightly different. It indicates that Machiavellian respondents: (1) would feel less guilty if underreporting income; (2) believes underreporting went against their principles to a lesser extent; (3) believes underreporting was less morally wrong; (4) believes underreporting was less unethical; and (5) believes underreporting was less dishonest. This pattern supports hypothesis $\left(H_{1}\right)$ that Machiavellian taxpayers will judge underreporting income as less unethical compared to Nonmachiavellian taxpayers.

Table 5

Descriptive statistics for underreporting ethics (comparison of two groups)

\begin{tabular}{llccc}
\hline Indicators & Code & $\begin{array}{c}\text { NonMACH } \\
\text { Mean } \\
\text { (Std. Dev.) }\end{array}$ & $\begin{array}{c}\text { MACH } \\
\text { Mean } \\
\text { (Std. Dev.) }\end{array}$ & $\begin{array}{c}\text { Variable } \\
\text { mean } \\
\text { difference }\end{array}$ \\
\hline $\begin{array}{l}\text { Not feeling guilty if underreport } \\
\begin{array}{l}\text { Underreporting goes against } \\
\text { principle }\end{array}\end{array}$ & TE1R & $4.78(1.83)$ & $3.55(1.51)$ & -1.23 \\
$\begin{array}{l}\text { Morally wrong to underreport } \\
\text { Not ethically wrong to underreport }\end{array}$ & TE3 & $5.09(1.55)$ & $3.91(1.51)$ & -1.18 \\
Dishonest to underreport & TE4R & $4.25(1.46)$ & $4.63(1.21)$ & -0.62 \\
& TE5 & $5.41(1.49)$ & $3.36(1.75)$ & -2.05 \\
\hline
\end{tabular}

$(R=$ reverse coded item)

The levels of agreement for each measurement on underreporting ethics were presented in Table 6. It showed that 60 percent of the respondents agreed that it is dishonest to underreport their income and 65 percent represented morally wrong to underreport. On the other hand, only 47 percent of them disagreed on the statement that it is not ethically wrong to underreport income. 
Table 6

Tax ethics questionnaire, with percentages of those responding to each statement

\begin{tabular}{|c|c|c|c|c|c|c|c|}
\hline Statements & & & Per & centages ( & & & \\
\hline & $\begin{array}{c}\text { Strongl } \\
y \\
\text { disagre } \\
\text { e }\end{array}$ & $\begin{array}{l}\text { Somewha } \\
\text { t disagree }\end{array}$ & $\begin{array}{c}\text { Slightly } \\
\text { disagre } \\
\text { e }\end{array}$ & $\begin{array}{c}\text { Neither } \\
\text { disagre } \\
\text { e nor } \\
\text { agree }\end{array}$ & $\begin{array}{l}\text { Slightl } \\
\text { y } \\
\text { agree }\end{array}$ & $\begin{array}{c}\text { Somewha } \\
\text { t agree }\end{array}$ & $\begin{array}{l}\text { Strongl } \\
\text { y agree }\end{array}$ \\
\hline $\begin{array}{l}\text { Not feeling } \\
\text { guilty if } \\
\text { underreport }\end{array}$ & 16.3 & 16.3 & 16.3 & 25.6 & 7.0 & 11.6 & 7.0 \\
\hline $\begin{array}{l}\text { Underreportin } \\
\text { g goes against } \\
\text { principle }\end{array}$ & & 7.0 & 18.6 & 23.3 & 9.3 & 23.3 & 18.6 \\
\hline $\begin{array}{l}\text { Morally } \\
\text { wrong to } \\
\text { underreport }\end{array}$ & & & 18.6 & 16.3 & 23.3 & 20.9 & 20.9 \\
\hline $\begin{array}{l}\text { Not ethically } \\
\text { wrong to } \\
\text { underreport }\end{array}$ & 20.9 & 7.0 & 18.6 & 14.0 & 27.9 & 9.3 & 2.3 \\
\hline $\begin{array}{l}\text { Dishonest to } \\
\text { underreport }\end{array}$ & 2.3 & 9.3 & 14.0 & 14.0 & 20.9 & 11.6 & 27.9 \\
\hline
\end{tabular}

Table 7

Descriptive statistics for underreporting ethical beliefs

\begin{tabular}{|c|c|c|c|c|c|c|}
\hline \multirow[t]{2}{*}{ Category } & \multicolumn{2}{|c|}{ Ethical } & \multicolumn{2}{|c|}{ Neutral } & \multicolumn{2}{|c|}{ Unethical } \\
\hline & Frequency & $\%$ & Frequency & $\%$ & Frequency & $\%$ \\
\hline $\begin{array}{l}\text { Not feeling guilty if } \\
\text { underreport }\end{array}$ & 21 & 48.8 & 11 & 25.6 & 11 & 25.6 \\
\hline $\begin{array}{l}\text { Underreporting goes } \\
\text { against principle }\end{array}$ & 22 & 51.1 & 10 & 23.3 & 11 & 25.6 \\
\hline $\begin{array}{l}\text { Morally wrong to } \\
\text { underreport }\end{array}$ & 28 & 65.1 & 7 & 16.3 & 8 & 18.6 \\
\hline $\begin{array}{l}\text { Not ethically wrong } \\
\text { to underreport }\end{array}$ & 20 & 46.5 & 6 & 13.9 & 17 & 39.6 \\
\hline $\begin{array}{l}\text { Dishonest to } \\
\text { underreport }\end{array}$ & 26 & 60.5 & 6 & 13.9 & 11 & 25.6 \\
\hline \multicolumn{7}{|c|}{$\begin{array}{l}\text { Vith regards to "comply" or "not comply", based on the hypothetical tax scenario } 1 \text {, it } \\
\text { ppeared that } 77 \text { percent of the respondents would "likely" do the same action of no } \\
\text { eporting their "casual income". Only } 23 \text { percent of the respondents will report their income } \\
\text { see Table 8). As for hypothetical tax scenario } 2 \text {, it was found that } 44 \text { percent of the } \\
\text { espondents were "likely" to report their "hobby income". Only } 56 \text { percent of the }\end{array}$} \\
\hline
\end{tabular}


Table 8

Descriptive statistics for tax compliance behaviour

\begin{tabular}{|c|c|c|c|c|}
\hline \multirow[t]{2}{*}{ Category } & \multicolumn{2}{|c|}{$\begin{array}{c}\text { Compliance Behaviour } 1 \\
\text { "casual income" }\end{array}$} & \multicolumn{2}{|c|}{$\begin{array}{l}\text { Compliance Behaviour } 2 \\
\text { "hobby income" }\end{array}$} \\
\hline & Frequency & $\%$ & Frequency & $\%$ \\
\hline Comply & 10 & 23.3 & 19 & 44.2 \\
\hline Not Comply & 33 & 76.7 & 24 & 55.8 \\
\hline
\end{tabular}

Table 9 shows that the majority of Nonmachiavellian respondents $(n=32)$ were considered as ethical taxpayers. It was found that 56 percent of the respondents felt guilty if underreport, 63 percent believed that underreporting is against principle, 69 percent believed that it is morally wrong to underreport, 56 percent believed that it is ethically wrong to underreport and 72 percent believed that it is dishonest to underreport. Consistent with hypothesis $\left(H_{1}\right)$, Machiavellian respondents were those who believed that underreporting ethics were less unethical (unethical taxpayers).

Table 9

Machiavellianism Vs Ethical Value

\begin{tabular}{|c|c|c|c|c|c|}
\hline \multirow[t]{2}{*}{ Indicators } & \multirow[t]{2}{*}{ Category } & \multicolumn{2}{|c|}{$\begin{array}{c}\text { Nonmachiavellians } \\
(n=32)\end{array}$} & \multicolumn{2}{|c|}{$\begin{array}{c}\text { Machiavellians } \\
\quad(n=11)\end{array}$} \\
\hline & & Frequency & $\%$ & Frequency & $\%$ \\
\hline \multirow[t]{3}{*}{ Not feeling guilty if underreport } & Ethical & 18 & 56.2 & 2 & 18.18 \\
\hline & Neutral & 4 & 12.5 & 2 & 18.18 \\
\hline & Unethical & 10 & 31.2 & 7 & 63.64 \\
\hline \multirow{3}{*}{$\begin{array}{l}\text { Underreporting goes against } \\
\text { principle }\end{array}$} & Ethical & 20 & 62.5 & 2 & 18.18 \\
\hline & Neutral & 5 & 15.6 & 5 & 45.46 \\
\hline & Unethical & 7 & 21.9 & 4 & 36.36 \\
\hline \multirow[t]{3}{*}{ Morally wrong to underreport } & Ethical & 22 & 68.7 & 6 & 54.55 \\
\hline & Neutral & 4 & 12.5 & 3 & 27.27 \\
\hline & Unethical & 6 & 18.8 & 2 & 18.18 \\
\hline \multirow[t]{3}{*}{ Not ethically wrong to underreport } & Ethical & 18 & 56.3 & 2 & 18.18 \\
\hline & Neutral & 4 & 12.5 & 2 & 18.18 \\
\hline & Unethical & 10 & 31.2 & 7 & 63.64 \\
\hline \multirow[t]{3}{*}{ Dishonest to underreport } & Ethical & 23 & 71.8 & 3 & 27.27 \\
\hline & Neutral & 5 & 15.6 & 1 & 9.09 \\
\hline & Unethical & 4 & 12.6 & 7 & 63.64 \\
\hline
\end{tabular}

When the Machiavellianism was cross tabulated with tax compliance behaviour, Table 10 shows that Machiavellian respondents chose to "not comply" of reporting both their "casual income" (100\%) and "hobby income" (91\%). It appeared that of those respondents who were Nonmachiavellian ( $n=32$ ), 69 percent chose to "not comply" of reporting their "casual income" but only 44 percent chose to "not comply" of reporting their "hobby income". Even though Nonmachiavellian respondents were considered as those who will follow, accept and 
obey the rules or law (Rayburn \& Rayburn, 1996), they will act differently in complying with tax if they feel there is a reason to do so. These findings support hypothesis $\left(H_{2}\right)$ that there is a relationship between taxpayer's Machiavellian orientations with tax compliance behaviour.

Table 10

Machiavellianism Vs Tax Compliance Behaviour

\begin{tabular}{llcccc}
\hline Type of Income & Category & $\begin{array}{c}\text { Nonmachiavellian } \\
\text { (n=32) }\end{array}$ & \multicolumn{2}{c}{$\begin{array}{c}\text { Machiavellian } \\
\text { (n=11) }\end{array}$} \\
\cline { 3 - 6 } & & Frequency & \% & Frequency & $\%$ \\
\hline Behaviour 1 & Comply & 10 & 31.3 & 0 & 0.0 \\
"Casual income" as a handyman & Not Comply & 22 & 68.7 & 11 & 100.0 \\
& & & & & \\
Behaviour 2 & Comply & 18 & 56.3 & 1 & 9.09 \\
$\begin{array}{l}\text { "hobby income" as a computer } \\
\text { expert }\end{array}$ & Not Comply & 14 & 43.7 & 10 & 90.9 \\
\hline
\end{tabular}

Table 11 shows that those respondents who chose to "comply" were those who were considered as ethical taxpayers. More than 50 percent of the respondents from both groups believed that underreporting goes against their principle, it is morally wrong to underreport, it is dishonest to underreport, it is ethically wrong to underreport and they feel guilty if they underreport income. Surprisingly, for those who chose to "not comply" were also those who were considered as ethical taxpayers. The percentages for those ethical respondents who chose to "not comply" were slightly lower for compliance behaviour 2 . These results showed that, ethical respondents made no difference in their tax compliance behaviour. Even though they were considered as ethical taxpayers, the majority of the respondents chose to "not comply" to report their "casual income" and "hobby income". 
Table 11

Underreporting ethics Vs tax compliance behaviour

\begin{tabular}{|c|c|c|c|c|c|c|c|c|c|}
\hline \multirow[t]{3}{*}{ Indicators } & \multirow[t]{3}{*}{ Category } & \multicolumn{4}{|c|}{ Compliance behaviour 1} & \multicolumn{4}{|c|}{ Compliance Behaviour 2} \\
\hline & & \multicolumn{2}{|c|}{$\begin{array}{l}\text { Comply } \\
(n=10)\end{array}$} & \multicolumn{2}{|c|}{$\begin{array}{c}\text { Not comply } \\
(n=33)\end{array}$} & \multicolumn{2}{|c|}{$\begin{array}{l}\text { Comply } \\
(n=19)\end{array}$} & \multicolumn{2}{|c|}{$\begin{array}{l}\text { Not comply } \\
(n=24)\end{array}$} \\
\hline & & $\begin{array}{c}\text { Freque } \\
\text { ncy }\end{array}$ & $\%$ & $\begin{array}{c}\text { Freque } \\
\text { ncy }\end{array}$ & $\%$ & $\begin{array}{c}\text { Freque } \\
\text { ncy }\end{array}$ & $\%$ & $\begin{array}{c}\text { Frequ } \\
\text { ency }\end{array}$ & $\%$ \\
\hline \multirow{4}{*}{$\begin{array}{l}\text { Not feeling guilty if } \\
\text { underreport }\end{array}$} & Ethical & 7 & 70. & 14 & 42. & 11 & 57.9 & 10 & 41.7 \\
\hline & Neutral & 1 & $\begin{array}{c}0 \\
10 . \\
0\end{array}$ & 10 & $\begin{array}{c}4 \\
30 . \\
3\end{array}$ & 4 & 21.1 & 7 & 29.2 \\
\hline & Unethica & 2 & 20 & 9 & 27. & 4 & 21.1 & 7 & 29.2 \\
\hline & 1 & & & & 3 & & & & \\
\hline \multirow{3}{*}{$\begin{array}{l}\text { Underreporting } \\
\text { goes against } \\
\text { principle }\end{array}$} & Ethical & 5 & 50 & 17 & 51. & 11 & 57.9 & 11 & 45.8 \\
\hline & Neutral & 3 & 30 & 7 & $\begin{array}{c}5 \\
21 . \\
2\end{array}$ & 5 & 26.3 & 5 & 20.8 \\
\hline & $\begin{array}{l}\text { Unethica } \\
\text { I }\end{array}$ & 2 & 20 & 9 & $\begin{array}{c}27 . \\
3\end{array}$ & 3 & 15.8 & 8 & 33.3 \\
\hline \multirow{3}{*}{$\begin{array}{l}\text { Morally wrong to } \\
\text { underreport }\end{array}$} & Ethical & 6 & 60 & 22 & 66. & 12 & 63.2 & 16 & 66.6 \\
\hline & Neutral & 2 & 20 & 5 & $\begin{array}{c}7 \\
15 . \\
2\end{array}$ & 2 & 10.6 & 5 & 20.8 \\
\hline & $\begin{array}{l}\text { Unethica } \\
\text { I }\end{array}$ & 2 & 20 & 6 & $\begin{array}{c}18 . \\
2\end{array}$ & 5 & 26.3 & 3 & 12.5 \\
\hline \multirow{3}{*}{$\begin{array}{l}\text { Not ethically wrong } \\
\text { to underreport }\end{array}$} & Ethical & 7 & 70 & 13 & 39. & 11 & 57.9 & 9 & 37.5 \\
\hline & Neutral & 1 & 10 & 5 & $\begin{array}{c}4 \\
15 . \\
2\end{array}$ & 2 & 10.5 & 4 & 16.7 \\
\hline & $\begin{array}{l}\text { Unethica } \\
\text { I }\end{array}$ & 2 & 20 & 15 & $\begin{array}{c}45 . \\
5\end{array}$ & 6 & 31.6 & 11 & 45.8 \\
\hline \multirow[t]{3}{*}{$\begin{array}{l}\text { Dishonest to } \\
\text { underreport }\end{array}$} & Ethical & 7 & 70 & 19 & $\begin{array}{c}57 . \\
6\end{array}$ & 16 & 84.2 & 10 & 41.7 \\
\hline & Neutral & 1 & 10 & 5 & $\begin{array}{c}15 . \\
2\end{array}$ & 1 & 5.3 & 5 & 20.8 \\
\hline & $\begin{array}{l}\text { Unethica } \\
\text { I }\end{array}$ & 2 & 20 & 9 & $\begin{array}{c}27 . \\
3\end{array}$ & 2 & 10.5 & 9 & 37.5 \\
\hline
\end{tabular}

In terms of relationship between Machiavellianism, underreporting ethics and tax compliance behaviour, as presented in Table 12, the result of Pearson correlation revealed that at 0.05 level of significance, Machiavellianism (MACH) has a significant relationship with compliance behaviour 1 ( $r=.323)$ and compliance behaviour $2(r=.414)$. Thus, hypothesis $\left(H_{2}\right)$ that there is a relationship between Machiavellianism and compliance behaviour is accepted. 
Machiavellianism also has significant relationship with underreporting ethics 2 ( $r=.306)$, underreporting $4(r=.332)$ and underreporting $5(r=.486)$. However respondent's ethical values did not have any significant relationship with compliance behaviour. Thus, hypothesis $\left(H_{3}\right)$ that there is a relationship between taxpayer's tax ethical beliefs and tax compliance behaviour is rejected.

Table 12

Correlations

\begin{tabular}{|c|c|c|c|c|c|c|c|c|}
\hline & MACH & $\begin{array}{c}\text { Complianc } \\
\mathrm{e} \\
\text { behaviour } \\
1\end{array}$ & $\begin{array}{c}\text { Complianc } \\
\mathrm{e} \\
\text { behaviour } \\
2\end{array}$ & $\begin{array}{c}\text { Tax } \\
\text { ethics } \\
1\end{array}$ & $\begin{array}{c}\text { Tax } \\
\text { ethics } \\
2\end{array}$ & $\begin{array}{c}\text { Tax } \\
\text { ethics } \\
3\end{array}$ & $\begin{array}{c}\text { Tax } \\
\text { ethics } \\
4\end{array}$ & $\begin{array}{c}\text { Tax } \\
\text { ethics } \\
5\end{array}$ \\
\hline $\mathrm{MACH}$ & 1.000 & & & & & & & \\
\hline $\begin{array}{l}\text { Complianc } \\
\text { e } \\
\text { behaviour } \\
1\end{array}$ & $.323^{*}$ & 1.000 & & & & & & \\
\hline $\begin{array}{l}\text { Complianc } \\
\text { e } \\
\text { behaviour } \\
2\end{array}$ & $.414^{* *}$ & $.619^{* *}$ & 1.000 & & & & & \\
\hline $\begin{array}{l}\text { Tax ethics } \\
1\end{array}$ & .292 & .177 & .146 & 1.000 & & & & \\
\hline $\begin{array}{l}\text { Tax ethics } \\
2\end{array}$ & $-.306^{*}$ & -.029 & -.175 & -.048 & 1.000 & & & \\
\hline $\begin{array}{l}\text { Tax ethics } \\
3\end{array}$ & -.076 & .045 & .109 & .023 & $.313^{*}$ & 1.000 & & \\
\hline $\begin{array}{l}\text { Tax ethics } \\
4\end{array}$ & $.332^{*}$ & .256 & .186 & $.342^{*}$ & -.097 & -.211 & 1.000 & \\
\hline $\begin{array}{l}\text { Tax ethics } \\
5\end{array}$ & $-.486^{* *}$ & -.097 & $-.402^{* *}$ & -.212 & $.328^{*}$ & .276 & -.203 & 1.000 \\
\hline
\end{tabular}

\section{Conclusion, Limitations and Future Research}

Given two hypothetical scenarios on tax compliance behaviour, the findings show that majority of the respondents chose to not comply to report their "casual income" and "hobby income". However the percentages of those who chose to not report their "casual income" are higher compared to "hobby income". Further analysis on Pearson correlation shows that there is a significant relationship between Machiavellianism and tax compliance behaviour which support hypothesis $\left(H_{2}\right)$ of the study. Thus, a possible explanation of this is that taxpayer's general ethical value is one of the factors that affect tax compliance behaviour. The majority of the Machiavellian respondents chose to not to report both incomes in their tax return. This is consistent with the findings by Ghosh and Crain (1995) who found that taxpayers with stronger Machiavellian orientations were more likely to engage in intentional non-compliance. 
Surprisingly, however when compared with those who were Nonmachiavellian respondents, the findings show that these respondents also chose to not to comply to report their "casual income" whereas on the other hand they chose to comply to report their "hobby income". This finding reveals that given a different situation and environment, regardless of their ethical value, respondents will act differently in tax compliance decision. A possible explanation of this is the belief that taxpayers should not be taxed equally with sole reference to income received without considering their financial responsibilities and social welfare. In this case, the "casual income" received by the handyman should not be taxed as the taxpayer in case needed the extra income to support his large family as compared to "hobby income" received by the taxpayer who has less financial responsibility.

This study however has limitations. First, the tax ethics was examined exclusively in the context of underreporting income. The findings cannot be generalise to over reporting of expenses or other forms of tax non-compliance. Second, the study utilised hypothetical tax non-compliance scenarios to obtain measures of intended tax compliance behaviour. No measure of actual behaviour was included in the study. Finally, the results of the findings were obtained merely from the questionnaire survey of respondents.

As this is a preliminary study on the relationship between Machiavellianism, tax ethics beliefs and compliance behaviour, further study with larger samples is taken to identify other factors that affect taxpayer's compliance behaviour such as the perceptions on the fairness of the tax system. Kaplan et al., (1997) says that it is possible that there may be an individual with higher moral value but might be less compliant because he or she judges a certain tax system to be unfair. Interview survey is suggested to be carried out to get a better understanding of tax compliance behaviour.

\section{Theoretical and Practical Contributions}

This paper will contribute several theoretical and practical contributions in the fields of sociological and psychological factors that may affect tax compliance behaviour among Malaysian taxpayers. The paper extends academic tax compliance research by proposing and testing both ethical value orientations that are general ethical (Machiavellianism) and tax ethical (underreporting ethics). Designing effective policies in enhancing tax compliance not only focusing on economic and deterrence factors, it requires understanding of the behavioural aspects of the tax compliance decision of the taxpayers.

Thus, the study examines the relationship between Machiavellianism, tax ethical beliefs and tax compliance behaviour. The findings provide evidence to support hypothesis $\left(H_{1}\right)$ that Machiavellian respondents judge underreporting ethics as less unethical compared to Nonmachiavellian respondents. Regarding ethical beliefs about underreporting, the majority of respondents believe that underreporting income is unethical. However, the findings revealed that there is no relationship between tax ethical value and compliance behaviour. It can be said that even though respondents judged underreporting income as unethical, this factor will not affect their tax compliance decision. Other than that, taxpayer's general ethical value is one of the factors that affect tax compliance behaviour. The majority of the Machiavellian respondents chose to not to report both incomes in their tax return because taxpayers with stronger Machiavellian orientations were more likely to engage in intentional non-compliance. 


\section{References}

Allingham, M. G., \& Sandmo, A. (1972), Income tax evasion: A theoretical analysis. Journal of Public Economics, 323-338.

Alm, J. (1991), A perspective on the experimental analysis of taxpayer reporting. The Accounting Review, 66(3), 577-593.

Alm, J., McClelland, G. H., \& Schultze, W. D. (1999), Changing social norms of tax compliance by voting. KYKLOS, 52(2), 141-171.

Bobek, D. D., \& Hatfield, R. C. (2003), An investigation of the theory of planned behaviour and the role of moral obligation in tax compliance. Behavioural Research in Accounting, 15, 13-38.

Bobek, D. D., Roberts, R. W., \& Sweeney, J. T. (2007), The social norms of tax compliance: Evidence from Australia, Singapore and the United States. Journal of Business Ethics, 74, 49-64.

Bodey, K., \& Grace, D. (2004), Examining self-monitoring, perceived control, self-efficacy and Machiavellianism in the context of complaint behaviour. Marketing Accountabilities and responsibilities. Australian \& New Zealand Marketing Academy.

Carroll, J. S. (1987), Compliance with the law: A decision-making approachto taxpaying. Law and Human Behaviour, 11(4), 319-335.

Chan, C. W., Troutman, C. S., \& O'Bryan, D. (2000), An expanded model of taxpayer compliance: Empirical evidence from the United States and Hong Kong. Journal of International Accounting, Auditing \& Taxation, 9(2), 83-103.

Choong, K. F. (2008), Malaysian Taxation: Principles and practice (14 ed.). Malaysia: Infoworld.

Christie, R., \& Geis, F. L. (1970), Studies in Machiavellianism. New York: Academic Press.

Cowell, F. A. (1985), The economic analysis of tax evasion. Bulletin of Economic Research, 37, 163-193.

Cuccia, A. D. (1994), The economics of tax compliance: What do we know and where do we go? Journal of Accounting Literature, 13, 81-103.

Darwish, S., Alzayed, S., \& Ahmed, U. (2020). How Women in Science can Boost Women's Entrepreneurship: Review and Highlights. International Journal of Innovation Creativity and Change, 14(1), 453-470.

Erard, B., \& Feinstein, J. S. (1994), Honesty and evasion in the tax compliance game. RAND Journal of Economics, 25(1 Spring), 1-19.

Geis, F., Weinheimer, S., \& Berger, D. (1970), Playing legislature: cool heads and hot issues. In R. Christie, \& F. L. Geis, Studies in Machiavellianism (pp. 190-209). New York: Academic Press.

Ghosh, D., \& Crain, T. L. (1995), Ethical standards, attitudes toward risk, and intentional noncompliance: An experimental investigation. Journal of Business Ethics, 14(5), 353365.

Hanefah, M. M. (2007), Tax systems taxpayer: Compliance and specific tax issues. Sintok: Universiti Utara Malaysia Press.

Hanno, D. M., \& Violette, G. R. (1996), An analysis of moral and social influences of taxpayer behaviour. Behavioural Research in Accounting, 8, 57-74.

Henderson, C., \& Kaplan, S. E. (2005), An examination of the role of ethics in tax compliance decisions. JATA, 27(1), 39-72.

Ho, D., \& Wong, B. (2006), An exploratory study of personal tax ethics in Hong Kong. The International Tax Journal, 32(2), 31-43. 
Ho, D., \& Wong, B. (2008), Issues on complianceand ethics in taxation: What do we know? Journal of Financial Crime, 15(4), 369-382.

Inland Revenue Board of Malaysia. (2002, 2003, 2004, 2005, 2006 \& 2007), Annual Report. Retrieved on 2008, from http://www.hasil.org.my

Jackson, B. R., \& Milliron, V. C. (1986), Tax compliance research: Findings, problems and prospects. Journal of Accounting Literature, 5, 125-165.

James, S., \& Alley, C. (2002), Tax compliance, self-assessment and tax administration. Journal of Finance and Management in Public Services, 2, 27-42.

Kaplan, S. E., \& Reckers, M. J. (1985), A study of tax evasion judgments. National Tax Journal(March), 97-102.

Kaplan, S. E., Newberry, K. J., \& Reckers, P. M. (1997), The effect of moral reasoning and educational communications on tax evasion intentions. JATA, 19(2), 38-54.

Kaplan, S. E., Reckers, M. J., \& Roark, S. J. (1988), An attribution theory analysis of tax evasion related judgments. Accounting, Organizations \& Society, 13(4), 371-379.

Kinsey, K. (1986), Theories and models of tax cheating. Criminal Justice, 403-425.

Kirchler, E. (2007), The economic psychology of tax behaviour. Cambridge: Cambridge University Press.

Kohlberg, L. (1969), Stages and sequences: The cognitive development approach to socialization. In Handbook of Socialization Theory and Research (pp. 347-480). Chicago: Rand McNally.

Long, D. K. (1976), An experimental investigation of selected communication effect of Machiavellianism. Speech Communication Association Convention.

McLaughlin, B. (1970), Incidental learning and Machiavellianism. Journal of Social Psychology, 82, 109-115.

Neuman, L. W. (2003), Social research methods, qualitative and quantitative approaches (5th ed.). USA: Pearson Education.

Plumley, A. H. (1996), The determinants of individual income tax compliance. Washington: IRS Research Division, Department of the Treasury Internal Revenue Service.

Rayburn, J. M., \& Rayburn, J. G. (1996), Relationship between Machiavellianism and Type A personality and ethical orientation. Journal of Business Ethics, 15, 1209-1219.

Reckers, P. M., Sanders, D. L., \& Roark, S. J. (1994), The influence of ethical attitudes on taxpayer compliance. National Tax Journal, 47(4), 825-836.

Roth, J. A., Scholz, J. T., \& Witte, A. D. (1989), Taxpayer compliance volume 1: An agenda for research. University of Pennsylvannia Press.

Shafer, W. E., \& Simmons, R. S. (2008), Social responsibility, Machiavellianism and tax avoidance: A study of Hong Kong tax professionals. Accounting, Auditing \& Accountability Journal, 21(5), 695-720.

Singh, V. (2003), Tax compliance and ethical decision making: A Malaysian perspective. Kuala Lumpur: Longman.

Singh, V. (2005), Tax thoughts on today's taxing times. Malaysia: Digibook Sdn Bhd.

Song, Y.-d., \& Yarbrough, T. E. (1978), Tax ethics and taxpayer attitudes: A survey. Public Administration Review(September/October), 442-452.

Torgler, B. (2002), Speaking to theorists and searching for facts: Tax morale and tax compliance in experiments. Journal of Economic Surveys, 16(5), 657-683.

Trivedi, V. U., Shehata, M., \& Lynn, B. (2003), Impact of personal and situational factors on taxpayer compliance: An experimental analysis. Journal of Business Ethics, 47, 175197. 
Trivedi, V. U., Shehata, M., \& Mestelman, S. (2005), Attitudes, incentives and tax compliance. Canadian Tax Journal, 53(1), 29-61.

Vogel, J. (1974), Taxation and public opinion in Sweden: An interpretation of recent survey data. National Tax Journal (pre-1986), 27(4), 499-513.

Webley, P., Cole, M., \& Eidjar, O.-P. (2001), The prediction of self-reported and hypothetical tax evasion: Evidence from England, France and Norway. Journal of Economic Psychology, 22, 141-155.

Wenzel, M. (2004a), An analysis of norm processes in tax compliance. Journal of Economic Psychology, 25(2), 213-228.

Wenzel, M. (2004b), The social side of sanctions: Personal and social norms as moderator of detterrence. Law and Human Behaviour, 28(5), 547-567.

Wenzel, M. (2005a), Motivation or rationalisation? Causal relations between ethics, norms and tax compliance. Journal of Economic Psychology, 26(4), 491-508.

Wenzel, M. (2005b), Misperceptions of social norms about tax compliance: From theory to intervention. Journal of Economic Psychology, 26, 862-883.

\section{Corresponding Author}

Vani Tanggamani is a Senior Lecturer at Faculty of Accountancy, Universiti Teknologi MARA (UiTM), Melaka, since 2006. Prior to joining UiTM, she worked as an Internal Auditor for several years. She obtained her PhD in Accounting from the Universiti Sains Malaysia. She has published few number of articles in the area of CSR in both local and international journals. In terms of practical experience, she has been involved in several training and research projects in Accounting related issues and Corporate Social Reporting in collaboration with industries. She is actively engaging in research activities in the field of Corporate Social Responsibility (CSR), Sustainable Development, Corporate Governance \& Business Performance and Accounting Education studies.

Tel No: +60102212997

Email :vani@uitm.edu.my 